\section{Determinant Factors of Customers Loyalty in Hotels in Bandung City}

Medianta Tarigan; Anastasia Wulandari; Rina Triyuningsih; Berthy Dwi Baroqah; Bela Merdianingsih

Department Psikologi, Universitas Pendidikan

Indonesia

e-mail:medianta@upi.edu;diangem2_psi@upi.edu;
Journal PSIKODIMENSIA

Volume 18, No. 2,

Juni - Desember 2019

ISSN cetak : 1411-6073

ISSN online : $2579-6321$

DOI : ....

\begin{abstract}
This research verified the direct causal effects between thinking styles, customer satisfaction and service quality toward the customer loyalty. On the other hand, the indirect causal effects were verified through mediation variable such as customer satisfaction, trust, customers engagement, switching barriers, and commitment. This research used path analysis as the data analysis technique. The result revealed that service quality affected customers loyalty directly and indirectly, customers satisfaction only affected the customers loyalty if was mediated, meanwhile thinking style didn't give significant direct and indirect effects towards customers loyalty.
\end{abstract}

Keywords: customer engagement, thinking styles, switching barriers, trust, customer satisfaction.

\section{PENDAHULUAN}

Dalam kehidupannya sehari-hari, manusia selalu dihadapkan pada banyak pilihan serta objek yang diamatinya. Masing-masing individu memiliki pendekatan tersendiri dalam mengolah dan mengevaluasi informasi, memecahkan masalah, serta membuat keputusan yang disebut juga sebagai gaya berpikir (Armstrong \& Cools, 2009); (Budijanto, 2013). Gaya berpikir sendiri dibagi menjadi dua tipe yaitu analytic dan holistic (Okazaki, Mueller, \& Diehl, 2013) Dengan adanya perbedaan tersebut maka bisa diasumsikan bahwa bila dihadapkan pada objek pengamatan yang sama, hasil evaluasinya mungkin pula akan berbeda karena pendapat setiap individu bersifat objektif. Jika dikaitkan dengan penelitian ini, maka ketika pelanggan menggunakan jasa hotel yang sama kemungkinan hasil evaluasi mengenai hotel tersebut akan berbeda dikarenakan adanya perbedaan gaya berpikir tersebut yang nantinya akan menentukan tingkat loyalitas pelanggan. Dari pernyataan-pernyataan di atas maka hipotesis dalam penelitian ini, yaitu "gaya berpikir berpengaruh terhadap loyalitas pelanggan hotel di Kota Bandung."

Selain berpengaruh terhadap loyalitas pelanggan, gaya berpikir juga diketahui mempengaruhi kepuasan pelanggan yang merupakan salah satu variabel penentu tingkat loyalitas pelanggan. Gaya berpikir analitik merupakan gaya berpikir yang cenderung menitikberatkan pada atribut objek untuk menetapkannya ke dalam kategori tertentu, dan preferensi untuk menggunakan peraturan tentang kategori tersebut untuk menjelaskan dan memprediksi perilaku objek (Becerra, Badrinarayanan, \& Kim, 2013). Gaya berpikir holistik diartikan sebagai gaya berpikir yang melibatkan orientasi ke 
dalam konteks atau bidang secara keseluruhan, termasuk memperhatikan hubungan antara objek fokus dan lapangan/bidang, dan preferensi untuk menjelaskan dan memprediksi kejadian berdasarkan hubungan tersebut (Becerra, Badrinarayanan, \& Kim, 2013). Pemikir holistik cenderung mempertimbangkan penyebab dari suatu kejadian (Song, Swaminathan, \& Anderson, 2015), sehingga apabila terjadi kesalahan saat karyawan melayani pemikir holistik cenderung bisa memaklumi atau menoleransi kesalahan tersebut. Dengan asumsi tersebut, maka hipotesis selanjutnya dari penelitian ini yaitu "gaya berpikir berpengaruh terhadap kepercayaan pelanggan hotel di Kota Bandung”. Dalam menanggapi publisitas negatif mengenai suatu produk, pemikir holistik cenderung mempertahankan sikap dan keyakinan yang dimilikinya sebelumnya terhadap suatu produk (Chang, 2014). Jadi, pemikir holistik cenderung tidak mudah terpengaruh oleh pemberitaan negatif mengenai suatu produk. Artinya jika pemikir holistik telah mempercayai pelayanan suatu hotel, maka tidak mudah untuk menghilangkan kepercayaan tersebut pada diri pelanggan tersebut dan sebaliknya pada pemikir analitik. Dengan demikian dari pernyataan-pernyataan sebelumnya bisa ditarik tiga hipotesis lainnya, yaitu 1) gaya berpikir berpengaruh terhadap kepercayaan pelanggan hotel di Kota Bandung; 2) gaya berpikir berpengaruh terhadap loyalitas pelanggan hotel di Kota Bandung melalui kepuasan pelanggan; dan 3) gaya berpikir berpengaruh terhadap loyalitas pelanggan hotel di Kota Bandung melalui kepercayaan.

Melalui beberapa penelitian diketahui bahwa terdapat beberapa faktor lainnya yang mempengaruhi loyalitas pelanggan, diantaranya adalah kualitas pelayanan (Minh \& Huu, 2016), kepuasan pelanggan (Ahdyanugroho, 2018), customer engagement (Hapsari,
Clemes, \& Dean, 2017), kepercayaan dan komitmen (Rai \& Medha, 2013)), switching barriers atau hambatan berpindah (Varshney, 2016); (Gisela \& Japarianto, 2014).

Ketika pelanggan telah memutuskan untuk menggunakan jasa hotel tertentu mereka telah memiliki ekspektasi bahwa hotel tersebut adalah hotel yang dapat memenuhi kebutuhan dan harapannya. Maka setelah mereka merasakan layanan yang diberikan selanjutnya mereka akan mengukur apakah yang mereka terima ini baik dan telah memenuhi kebutuhan atau harapan mereka. Ukuran dari seberapa baik layanan yang diberikan dalam memenuhi harapan dari pelayanan yang ada ini disebut service quality (Ramseook, 2010). Hal ini berarti citra kualitas yang baik bukanlah berdasarkan pada sudut pandang atau persepsi dari penyedia jasa melainkan berdasarkan sudut pandang atau persepsi pelanggan (Yunus \& Budianto, 2014). Service quality yang baik atau dengan kata lain pelayanan yang unggul akan berpengaruh terhadap munculnya customer loyalty atau loyalitas pelanggan. Dengan demikian, bisa disimpulkan bahwa hipotesis lainnya dari penelitian ini yaitu "service quality berpengaruh terhadap loyalitas pelanggan hotel di Kota Bandung."

Salah satu cara yang digunakan perusahaan atau dalam hal ini hotel untuk mempertahankan konsumen yaitu memperhatikan kualitas produk/jasa agar memenuhi harapan konsumen (Kotler \& Keller, 2016). Sebelum pelanggan menjadi loyal karena pelayanan yang diberikan, terdapat faktor lain yang menjadi perantaranya. Penelitian yang dilakukan Bhakar, Bhakar, dan Bhakar (2015) menemukan bahwa service quality yang unggul akan menimbulkan kepuasan pelanggan atau customer satisfaction. Customer satisfaction adalah evaluasi atau penilaian secara keseluruhan pelanggan terhadap suatu produk pasca pembelian (Michael, 
2015). Ini berarti ketika pelanggan telah menerima pelayanan yang unggul mereka akan menilai bahwa penyedia jasa memiliki pelayanan yang baik maka akan muncul kepuasan pada diri mereka. Maka muncul tiga hipotesis lainnya yaitu 1) "service quality berpengaruh terhadap kepuasan pelanggan hotel di Kota Bandung", 2) "kepuasan pelanggan berpengaruh terhadap loyalitas pelanggan hotel di Kota Bandung", 3) "service quality berpengaruh terhadap loyalitas pelanggan hotel di Kota Bandung melalui kepuasan pelanggan.”

Selain kepuasan pelanggan, terdapat perantara lainnya antara service quality dengan loyalitas pelanggan yaitu customer engagement. Customer engagement muncul ketika pelanggan benar-benar partisipasi dengan kegiatan yang berhubungan dengan perusahaan yang mana dimulai oleh pelanggan atau perusahaan (Vivek, Beatty, \& Morgan, 2012). Perilaku yang menandakan pelanggan memiliki engagement adalah perilaku yang muncul di luar aktivitas pembelian terhadap merek (perusahaan) seperti word of mouth, rekomendasi, interaksi antar konsumen, bloging, menulis review dan aktivitas lain yang sejenis (MSI, 2010). Perilaku-perilaku tersebut dapat muncul ketika pelayanan yang diterima pelanggan telah memenuhi harapan atau kebutuhannya, dengan kata lain service quality yang dimiliki penyedia jasa ialah unggul. Penelitian yang menemukan bahwa service quality berpengaruh terhadap customer engagement dilakukan oleh Puriwat dan Tripopsakul (2014). Individu atau pelanggan yang terlibat cenderung mengembangkan sikap yang lebih baik terhadap produk, perusahaan, atau merek, yang mengarah ke kesetiaan terhadap entitas (Vivek, Beatty, \& Morgan, 2012); (So, King, Sparks, \& Wang, 2014). Hal ini berarti pelanggan yang telah engage terhadap suatu produk akan memiliki kesetiaan atau loyal terhadap produk. Partisipasi mereka terhadap setiap kegiatan yang berkaitan dengan perusahaan membuat mereka hanya fokus terhadap satu merek atau satu perusahaan saja. Ini menjadikan kecenderungan untuk beralih pada pesaing ialah kecil. Hal ini tentu membuat mereka akan membeli produk secara berulang atau dengan kata lain loyal. Penelitian yang membuktikan bahwa engagement berpengaruh terhadap loyalty ditemukan oleh Hapsari, Clemes, dan Dean (2017). Berdasarkan pernyataan-pernyataan tersebut, maka bisa ditarik tiga hipotesis lainnya, diantaranya adalah 1) "service quality berpengaruh terhadap customer engagement dari pelanggan hotel di Kota Bandung", 2) "customer engagement berpengaruh terhadap loyalitas pelanggan hotel di Kota Bandung", 3) "service quality berpengaruh terhadap loyalitas pelanggan hotel di Kota Bandung melalui customer engagement. Rai dan Medha (2013) menghasilkan penelitian yang membuktikan bahwa tingkat komitmen dan kepercayaan konsumen menentukan tingkat loyalitas secara signifikan. Walaupun pengusaha hotel memerlukan usaha yang lebih keras dan waktu yang lebih lama untuk memperoleh kepercayaan pelanggan, namun jika kepercayaan telah terbentuk maka akan memberikan beberapa manfaat mengarah pada terbentuknya loyalitas pelanggan. . Untuk membangun kepercayaan konsumen, penting bagi penyedia jasa untuk memberikan informasi terpercaya, seperti informasi mengenai fasilitas, harga, maupun promosi-promosi yang sedang berlangsung, karena semakin tinggi tingkat kepercayaan konsumen terhadap penyedia jasa, maka semakin tinggi pula tingkat loyalitas konsumen terhadap penyedia jasa tersebut (Achyar $\&$ Brilliant, 2013). Tabrani dkk (Tabrani, Amin, \& Nizam, 2018) menyatakan bahwa kepercayaan sendiri memiliki pengaruh signifikan terhadap komitmen yang menumbuhkan kekebalan dalam 
diri konsumen terhadap usaha hotel pesaing untuk menarik pelanggan tersebut (Wu, 2011). Jika pelanggan merasa terikat dengan suatu hotel, maka mereka akan terus menerus menggunakan jasa hotel yang sama (Risdianto \& Japarianto, 2014), menunjukan kekebalan terhadap usaha hotel pesaing untuk menarik pelanggan tersebut (Jannah, Mawardi, \& Abdullah, 2017), serta menstimulus pelanggan untuk mencoba menggunakan bermacam-macam fasilitas yang ditawarkan oleh pihak hotel (Risdianto \& Japarianto, 2014). Perilaku tersebut merupakan atribut loyalitas pelanggan yang menandai bahwa pelanggan tersebut merupakan pelanggan yang memiliki loyalitas tinggi. Dengan demikian, terbentuklah hipotesis lainnya yaitu "kepercayaan berpengaruh terhadap loyalitas pelanggan hotel di Kota Bandung."

Setelah konsumen menemukan kepuasan terhadap Hotel, maka konsumen akan menjadi sulit untuk berpindah ke Hotel lain atau yang biasa disebut dengan hambatan berpindah. Disini hambatan berpindah memiliki peran sebagai variabel penyesuai pada hubungan antara kepuasan pelanggan dan loyalitas pelanggan, atau dengan kata lain, ketika tingkat kepuasan pelanggan dan loyalitas pelanggan ini akan bervariasi tergantung pada kuatnya hambatan berpindah yang dirasakan oleh konsumen (Novianti, Suryoko, \& Nugraha, 2013). Ketika hambatan berpindah yang dimiliki oleh konsumen dapat dikatakan cukup kuat maka hubungan tersebut akan berlanjut menjadi komitmen. Komitmen merupakan salah satu faktor yang penting untuk membuat konsumen menjadi loyal (Bricci, Fragata, \& Antunes, 2015), karena komitmen ini memiliki peran sebagai yang akan memunculkan niat konsumen untuk melakukan pembelian ulang terhadap suatu produk/jasa yang sedang digunakan oleh konsumen
(Sugiyarmasto \& Sudarmadi, 2012). Ketika konsumen sudah berniat untuk melakukan pembelian ulang terhadap produk yang sama, berarti konsumen sudah merasakan kenyamanan dan keamanan dalam membangun hubungan untuk jangka panjang dengan pihak perusahaan yang memberikan produk/jasa atau dengan kata lain konsumen tersebut sudah merasa loyal terhadap produk/jasa yang dipilihnya (Bastiar, 2010). Berdasarkan pernyataanpernyataan di atas maka bisa ditarik enam hipotesis lainnya, yaitu 1) "kepuasan pelanggan berpengaruh terhadap hambatan berpindah pelanggan di Kota Bandung", 2) "kepuasan pelanggan berpengaruh terhadap komitmen pelanggan hotel di Kota Bandung", 3) "komitmen berpengaruh terhadap loyalitas pelanggan hotel di Kota Bandung", 4) "hambatan berpindah berpengaruh terhadap loyalitas pelanggan hotel di Kota Bandung", 5) "kepuasan pelanggan berpengaruh terhadap loyalitas pelanggan hotel di Kota Bandung melalui hambatan berpindah", 6) "kepuasan pelanggan berpengaruh terhadap loyalitas pelanggan hotel di Kota Bandung melalui komitmen."

Maka penelitian ini bermanfaat bagi pembaca untuk mengetahui dinamika pengaruh variabel-variabel yang menjadi faktor penentu terbentuknya loyalitas pelanggan hotel di Kota Bandung, baik pengaruh langsung maupun pengaruh tidak langsungnya terhadap loyalitas pelanggan.

\section{METODE}

Pendekatan yang digunakan dalam penelitian ini adalah pendekatan kuantitatif dengan metode analisis jalur. Metode analisis jalur dilakukan untuk menganalisis pola hubungan antar variabel yang bertujuan untuk mengetahui hubungan langsung maupun tidak langsung seperangkat variabel eksogen dan endogen. Teknik 
pengambilan sampel yang digunakan dalam penelitian ini adalah teknik nonprobability sampling dengan teknik accidental sampling. Kriteria subjek penelitiannya adalah Warga Negara Indonesia yang pernah menginap di Hotel yang berada di Kota Bandung. Penelitian dilakukan kepada 349 orang dengan kriteria tersebut. Terdapat delapan variabel dalam penelitian ini, diantaranya adalah:

a. Service quality atau Kualitas pelayanan merupakan perbandingan antara hasil persepsi pelanggan terhadap pelayanan yang diberikan dengan ekspektasi atau harapannya. Pengukuran dilakukan menggunakan kuesioner yang diadaptasi dari penelitian yang dilakukan oleh Parasuraman, Zeithaml, dan Berry (1993). Reliabilitas dari instrumen yang telah diadaptasi oleh peneliti adalah 0,95 .

b. Customer satisfaction atau Kepuasan pelanggan merupakan penilaian yang diberikan oleh pelanggan setelah menggunakan jasa hotel. Kepuasan pelanggan diukur menggunakan kuesioner yang diadaptasi dari penelitian yang dilakukan oleh Amin, Yahya, Ismayatim, Nasharuddin, dan Kassim (2013). Reliabilitas instrument ini adalah 0,78.

c. Customer Engagement merupakan motivasi pelanggan untuk terlibat dalam setiap kegiatan yang berhubungan dengan hotel, termasuk merekomendasikan hotel terhadap calon pelanggan, berinteraksi dengan pelanggan hotel yang sama, menulis review mengenai hotel dan kegiatankegiatan lainnya yang berhubungan deng hotel. Customer engagement diukur menggunakan kuesioner yang diadaptasi dari So, King, Sparks, dan Wang (2014) dengan reliabilitas 0,96 .

d. Thinking style atau Gaya berpikir merupakan cara yang cenderung lebih sering digunakan oleh individu untuk memfungsikan kognisinya untuk mengatur kegiatannya seharihari termasuk membuat keputusan. Pengukuran dilakukan menggunakan kuesioner yang diadaptasi dari Analysis-Holism Scale oleh (Becerra, Badrinarayanan, \& Kim, 2013) dengan reliabilitas sebesar 0,66.

e. Trust atau Kepercayaan merupakan perasaan yang timbul pada diri seseorang bahwa suatu hotel bisa diandalkan dalam memenuhi kebutuhan akomodasinya sehingga memutuskan untuk menyewa hotel tersebut. Pengukuran dilakukan dengan kuesioner yang diadaptasi dari Singh dan Jain (2015) dan didapatkan reliabilitas sebesar 0,92.

f. Customer loyalty atau loyalitas pelanggan merupakan sikap dan tindakan pelanggan yang dilakukan secara sukarela yang menguntungkan bagi hotel. Pengukuran dilakukan menggunakan kuesioner yang diadaptasi dari Bobalca, Gatej, dan Ciobanu (2012) dan didapatkan reliabilitas sebesar 0,96.

g. Switching barriers atau hambatan berpindah merupakan kesulitan yang muncul dalam diri pelanggan ketika akan berpindah dari produk yang telah digunakan karena adanya pertimbangan masalah ekonomi, sosial, dan psikologis yang akan didapatkan jika berpindah ke produk lain. Pengukuran dilakukan menggunakan kuesioner yang diadaptasi dari Han, Kim, dan Hyun (2011). Setelah 


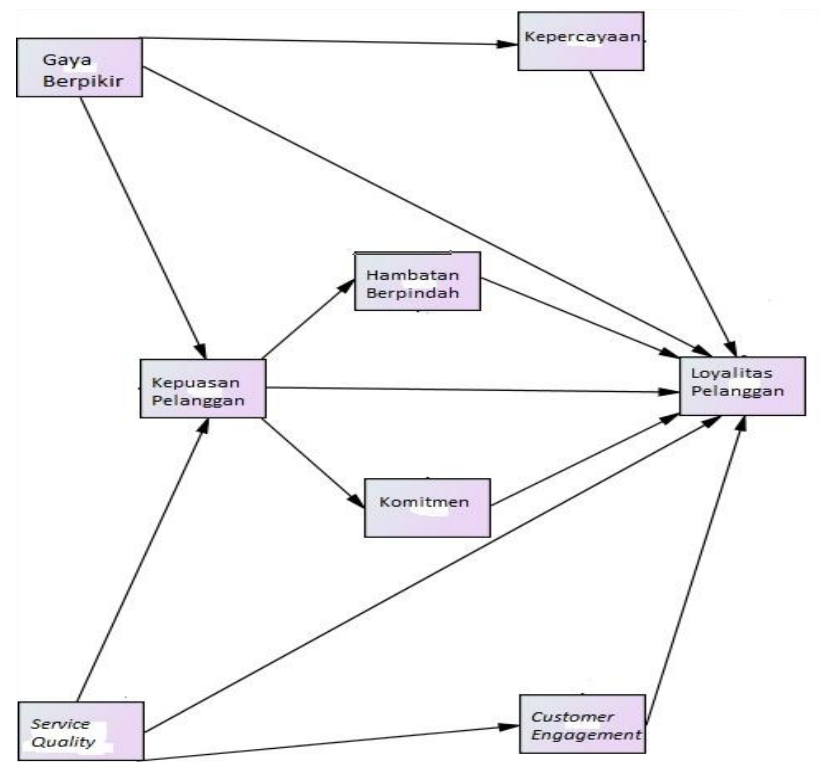

Gambar 1: Model Struktural pada Penelitian

diadaptasi dari Han, Kim, dan Hyun (2011). Setelah diuji didapatkan reliabilitas sebesar 0,94 .

h. Commitment merupakan hubungan yang terjadi ketika seseorang telah percaya kepada suatu poduk/jasa sehingga pelanggan memiliki pemikiran untukbertahan menggunakan jasa tersebut dalam jangka waktu yang lama. Komitmen diukur menggunakan kuesioner yang diadaptasi dari Beatson, Coote dan Rudd (2006) dan didapatkan reliabilitas sebesar 0,96 .

\section{HASIL DAN DISKUSI}

Gambar 1 menggambarkan model struktural penelitian yang diuji. Adapun, tabel 1 dan tabel 2 menunampilkan hasil pengujian hipotesis berupa Regression Weights dan koefisien perbandingan pengaruh langsung dan pengaruh tidak langsung dapat dilihat pada bagian lampiran.

Berdasarkan telaah literatur, peneliti belum menemukan penelitian serupa yang melibatkan kedelapan variabel dalam penelitian ini. Berdasarkan uji hipotesis yang disajikan pada tabel 1, diketahui bahwa gaya berpikir hanya mempengaruhi kepercayaan dan tidak memiliki pengaruh langsung terhadap kepuasan pelanggan dan loyalitas pelanggan. Kepuasan pelanggan dan kepercayaan sendiri bisa menjadi variabel mediasi antara gaya berpikir terhadap loyalitas, namun pengaruhnya tidak signifikan. Dengan kata lain, tidak ada perbedaan signifikan antara tingkat kepuasan dan loyalitas pelanggan yang memiliki gaya berpikir holistik dengan pelanggan dengan gaya berpikir analitik. Nilai CR (critical ratio) pada pengaruh gaya berpikir terhadap kepercayaan adalah sebesar 2,044 dan positif, artinya pelanggan dengan gaya berpikir holistik cenderung lebih mudah dalam membentuk dan mempertahankan kepercayaannya terhadap hotel dibandingkan pelanggan dengan gaya berpikir analitik. Hal ini sejalan dengan hasil penelitian yang dilakukan oleh Monga dan John (2010) yang mengatakan bahwa kesuksesan ekstensi atau perluasan brand dipengaruhi oleh gaya berpikir pelanggan. Pelanggan yang memiliki gaya berpikir holistik cenderung menghubung-hubungkan informasi yang dimilikinya. Maka dari 
itu bisa disimpulkan bahwa pemikir holistik cenderung menghubungkan antara parent brand dengan brand extension-nya. Dengan demikian, pelanggan hotel dengan gaya berpikir holistik cenderung menganggap kualitas hotel utama (parent brand) sama dengan cabang dari hotel (extension brand). Jika dikaitkan dengan salah satu dimensi kepercayaan yaitu :

\begin{tabular}{|c|c|c|c|c|c|c|c|c|}
\hline & \multicolumn{3}{|c|}{ Path } & Estimate & S.E. & C.R. & $\mathbf{P}$ & Hasil \\
\hline H1 & $\begin{array}{l}\text { Kepuasan } \\
\text { Pelanggan }\end{array}$ & $<--$ & Service Quality & ,414 & ,031 & 13,292 & $* * *$ & Diterima \\
\hline $\mathbf{H 2}$ & $\begin{array}{l}\text { Kepuasan } \\
\text { Pelanggan }\end{array}$ & $<--$ & Gaya Berpikir & ,043 & ,051 & 837 & ,403 & Ditolak \\
\hline H3 & $\begin{array}{l}\text { Hambatan } \\
\text { Berpindah }\end{array}$ & $\begin{array}{l}<-- \\
\end{array}$ & $\begin{array}{l}\text { Kepuasan } \\
\text { Pelanggan }\end{array}$ & ,898 & ,102 & 8,823 & $* * *$ & Diterima \\
\hline H4 & Komitmen & $<--$ & $\begin{array}{l}\text { Kepuasan } \\
\text { Pelanggan }\end{array}$ & ,476 &, 060 & 7,870 & $* * *$ & Diterima \\
\hline H5 & Kepercayaan & $<---$ & Gaya Berpikir &, 110 & 054 & 2,044 & ,041 & Diterima \\
\hline H6 & $\begin{array}{l}\text { Customer } \\
\text { Engagement }\end{array}$ & $<--$ & Service Quality &, 524 & ,062 & 8,435 & $* * *$ & Diterima \\
\hline H7 & $\begin{array}{l}\text { Loyalitas } \\
\text { Konsumen }\end{array}$ & $\begin{array}{l}<-- \\
\end{array}$ & $\begin{array}{l}\text { Kepuasan } \\
\text { Pelanggan } \\
\end{array}$ &, 060 & ,047 & 1,282 & 200 & Ditolak \\
\hline H8 & $\begin{array}{l}\text { Loyalitas } \\
\text { Konsumen }\end{array}$ & $<--$ & $\begin{array}{l}\text { Hambatan } \\
\text { Berpindah }\end{array}$ & 133 & ,018 & 7,437 & $* * *$ & Diterima \\
\hline H9 & $\begin{array}{l}\text { Loyalitas } \\
\text { Konsumen }\end{array}$ & <--- & Komitmen & ,519 & ,030 & 17,277 & $* * *$ & Diterima \\
\hline H10 & $\begin{array}{l}\text { Loyalitas } \\
\text { Konsumen }\end{array}$ & $\begin{array}{l}<-- \\
\end{array}$ & Kepercayaan & ,051 & ,040 & 1,291 & , 197 & Ditolak \\
\hline H11 & $\begin{array}{l}\text { Loyalitas } \\
\text { Konsumen }\end{array}$ & $\begin{array}{l}<-- \\
\end{array}$ & $\begin{array}{l}\text { Customer } \\
\text { Engagement }\end{array}$ &,- 012 & ,021 &,- 588 & ,557 & Ditolak \\
\hline H12 & $\begin{array}{l}\text { Loyalitas } \\
\text { Konsumen }\end{array}$ & <--- & Service Quality &, 114 & ,032 & 3,593 & $* * *$ & Diterima \\
\hline H13 & $\begin{array}{l}\text { Loyalitas } \\
\text { Konsumen }\end{array}$ & $\begin{array}{l}<-- \\
\end{array}$ & Gaya Berpikir &,- 019 & ,040 &,- 483 & ,629 & Ditolak \\
\hline
\end{tabular}

Tabel 1: Regression Weights (Group number 1 - Default model)

Ket: $* * *$ signifikan $p<0,001$

experience (Singh \& Jain, 2015), maka pemikir holistik akan mengikutsertakan pengalamannya menggunakan hotel dengan brand yang sama saat menggunakan hotel lain dengan brand yang sama walaupun mereka belum pernah menggunakan hotel tersebut. Artinya, jika pelanggan dengan gaya berpikir holistik telah mempercayai suatu brand maka tidak akan sulit untuk membentuk kepercayaan tersebut pada cabang brand hotel tersebut. Pemikir holistik juga cenderung mempertahankan kepercayaan atau evaluasi yang telah mereka miliki terhadap suatu objek atau dalam hal ini hotel sehingga apabila mendengar pemberitaan negative mengenai hotel yang telah mereka percayai, pemikir holistik cenderung tidak terpengaruh oleh berita tersebut (Chang, 2014) 
Tabel 2: Perbandingan Pengaruh Langsung dan Pengaruh Tidak Langsung

\begin{tabular}{llccc}
\hline & \multicolumn{1}{c}{ Path } & $\begin{array}{c}\text { Direct } \\
\text { effect }\end{array}$ & $\begin{array}{c}\text { Indirect } \\
\text { effect }\end{array}$ & Results \\
\hline H14 & Gaya Berpikir $\rightarrow$ Loyalitas Pelanggan & $\mathbf{- 0 , 0 1 6}$ & $\mathbf{0 , 0 2 0}$ & Mediated \\
\hline H15 & Service Quality $\rightarrow$ Loyalitas Pelanggan & $\mathbf{0 , 1 5 3}$ & $\mathbf{0 , 2 2 9}$ & Mediated \\
\hline H16 & $\begin{array}{l}\text { Kepuasan Pelanggan } \rightarrow \text { Loyalitas } \\
\text { Pelanggan }\end{array}$ & $\mathbf{0 , 0 5 8}$ & $\mathbf{0 , 3 5 1}$ & Mediated \\
\hline
\end{tabular}

Pengaruh service quality terhadap loyalitas pelanggan secara langsung atau tanpa mediasi yakni sebesar 0,114 . Total pengaruh tidak langsung atau melalui mediasi berupa variabel kepuasan pelanggan dan customer engagement adalah sebesar 0,229. Dari perbandingan tersebut bisa diketahui bahwa pengaruh tidak langsung antara service quality terhadap loyalitas pelanggan, lebih besar dibandingkan pengaruh langsungnya. Artinya service quality berpengaruh terhadap loyalitas pelanggan, baik secara langsung maupun tidak langsung, selain itu variabel kepuasan pelanggan dan customer engagement memediasi pengaruh service quality terhadap loyalitas pelanggan.

Pelanggan yang merasa puas terhadap service quality yang diterimanya dari hotel akan muncul loyalitas. Kepuasan pelanggan terbentuk ketika ekspektasi mereka mengenai hotel yang bersangkutan terpenuhi yang menyebabkan pelanggan cenderung ingin mengulangi kembali pengalaman memuaskannya menggunakan jasa hotel bersangkutan. Dengan terjadinya pembelian kembali atau penggunaan kembali jasa hotel yang sama maka terbentuklah loyalitas pelanggan. Pada pelanggan yang memiliki engagement yang tinggi dikarenakan ekspektasi mereka yang terpenuhi juga akan muncul loyalitas pelanggan. Engagement yang tinggi menyebabkan pelanggan hanya fokus terhadap satu hotel tertentu saja dan membuat mereka berpartisipasi dalam kegiatan-kegiatan yang berhubungan dengan hotel yang bersangkutan, termasuk membeli produk maupun jasa yang ditawarkan hotel. Dengan demikian, semakin intens frekuensi pelanggan dalam mengikuti kegiatan-kegiatan dan menggunakan jasa hotel maka semakin mungkin pula bagi mereka untuk merekomendasikan hotel tersebut kepada orang lain (Hapsari, Clemes, \& Dean, 2017).

Pengaruh kepuasan pelanggan terhadap loyalitas pelanggan secara langsung atau tanpa mediasi yakni sebesar 0,060. Total pengaruh tidak langsung atau melalui mediasi berupa variabel komitmen dan hambatan berpindah adalah sebesar 0,351. Dari perbandingan tersebut bisa diketahui bahwa pengaruh tidak langsung antara service quality terhadap loyalitas pelanggan, lebih besar dibandingkan pengaruh langsungnya. Dengan demikian bisa disimpulkan bahwa kepuasan pelanggan tidak memiliki pengaruh langsung yang signifikan terhadap loyalitas pelanggan, namun memiliki pengaruh tidak langsung apabila dimediasi oleh komitmen dan hambatan berpindah.

Hasil tersebut membuktikan penelitian sebelumnya yang dilakukan oleh Riskiyati (2012) yang menyatakan bahwa kepuasan pelanggan berpengaruh positif dan signifikan terhadap loyalitas pelanggan dengan mediasi komitmen pelanggan. Komitmen ini terbentuk ketika pelanggan merasakan kepuasan berulang kali hingga menimbulkan loyalitas dalam diri pelanggan (Suparmi \& Handhoko, 2018). Selain itu, penelitian yang dilakukan oleh Juana dkk (Juana, Sukaatmadja, \& Yasa, 2017) membuktikan bahwa kepuasan pelanggan memiliki hasil yang positif dan signifikan terhadap loyalitas pelanggan melalui switching cost yang merupakan variabel hambatan berpindah. 
Salah satu perilaku yang muncul ketika pelanggan memiliki hambatan berpindah yang tinggi yaitu merekomendasikan produk/jasa yang digunakan kepada orang lain. Perilaku tersebut merupakan salah satu indikator action loyalty dimana saat merekomendasikan hotel, pelanggan akan menyebutkan hal-hal positif mengenai hotel yang bersangkutan dan memungkinkan orang lain untuk menggunakan jasa hotel yang direkomendasikan tersebut (Bobalca , Gatej, \& Ciobanu, 2012).

\section{SIMPULAN}

Berdasarkan penelitian yang telah dilakukan, peneliti menyimpulkan dan menyarankan beberapa hal sebagai berikut:

1. Gaya berpikir tidak memiliki pengaruh langsung terhadap loyalitas pelanggan dan pengaruh tidak langsungnya atau pengaruhnya apabila dimediasi oleh kepercayaan dan kepuasan pelanggan pun tidak signifikan. Maka dari itu, peneliti selanjutnya sebaiknya mencari sikap konsumen lain atau sisi psikologis lain dari konsumen yang mungkin memberikan pengaruh yang signifikan terhadap loyalitas pelanggan.

2. Service quality memiliki pengaruh baik secara langsung maupun tidak langsung terhadap loyalitas pelanggan. Dengan kata lain service quality yang tinggi akan

\section{DAFTAR PUSTAKA}

Achyar, A., \& Brilliant, M. A. (2013). The impact of satisfaction and trust on loyalty of e-commerce customers. Asean Marketing Journal, 51-58. menyebabkan tingkat loyalitas pelanggan yang tinggi pula, namun kemungkinan loyalitas pelanggan terbentuk akan meningkat apabila dimediasi oleh kepuasan pelanggan dan customer engagement. Artinya dengan service quality yang tinggi akan menimbulkan kepuasan pelanggan dan engagement yang tinggi pula dan akhirnya merujuk pada terbentuknya loyalitas pelanggan. Maka pengusaha hotel hendaknya menjaga dan meningkatkan service quality hotel untuk menghasilkan kepuasan dan membentuk engagement dalam diri pelanggan, sehingga menjamin loyalitas pelanggan terhadap hotel.

3. Kepuasan pelanggan tidak memiliki pengaruh langsung terhadap loyalitas pelanggan namun memiliki pengaruh yang signifikan apabila dimediasi oleh hambatan berpindah dan komitmen. Dengan kata lain, pelanggan yang puas belum tentu loyal terhadap hotel, namun apabila pelanggan tersebut berkomitmen dan memiliki hambatan berpindah yang tinggi pada hotel maka akan menimbulkan loyalitas pelanggan. Maka untuk membentuk loyalitas pelanggan terhadap hotel, pengusaha hotel hendaknya berfokus untuk meningkatkan hambatan berpindah dan komitmen pelanggan.
Ahdyanugroho, R. (2018). Pengaruh kualitas pelayanan terhadap loyalitas pelanggan dengan kepuasan dan kepercayaan sebagai variabel mediasi (studi pada pelanggan jasa kebersihan King Clean di D.I. Yogyakarta). Yogyakarta: Universitas Muhammadiyah Yogyakarta.


Armstrong, S., \& Cools, S. (2009). Cognitive styles and their relevance for business and management. New York: Springer.

Bastiar, Z. (2010). Service exzellent dalam rangka membentuk loyalitas pelanggan. Manajerial, 54-65.

Becerra, E., Badrinarayanan, V., \& Kim, C. (2013). Influence of thinking tendencies on online transaction of hybrid relatilers. Journal of Business Research, 336-344.

Bhakar, S., Bhakar, S., \& Bhakar, S. (2015). Customer satisfaction or service quality-identifying mediating variable and evaluating behavioral intention model in hotel industry: an sem approach. The International Journal Research Publication's Research Journal of Social Science \& Management, 111-124.

Bobalca , C., Gatej, C., \& Ciobanu, O. (2012). Developing a scale to measure customer loyalty. Procedia Economics and Finance, 623-628.

Bricci, L., Fragata, A., \& Antunes, J. G. (2015). The Effects of Trust, Commitment and Satisfaction on Customer Loyalty in the distribution sector. Journal of Business Economics and Management, 1-5.

Budijanto, R. (2013). Thinking styles, teamwork quality and performance. Australia: University of Canberra.
Chang, S. S. (2014). Does style of thinking make differences in cosumer judgments on brand extension. Comtemporary Management Research, 165-178.

Gisela, E., \& Japarianto, E. (2014). Pengaruh customer satisfaction dan switching barrier terhadap customer loyalty dengan customer trust sebagai variabel moderating pada toko bunga Petra Togamas Surabaya. Jurnal Manajemen Pemasaran Petra, 1-10.

Hapsari, R., Clemes, M., \& Dean, D. (2017). The impact of service quality, customer engagement and selected marketing constructs on airline passanger loyalty. International Journal of Quality and Service Sciences, 21-40.

Jannah, A., Mawardi, K., \& Abdullah. (2017). Pengaruh Customer Relationship Management pada Kepuasan dan Loyalitas Pelanggan. Jurnal Administrasi Bisnis, 38-45.

Juana, I. R., Sukaatmadja, I. G., \& Yasa, N. K. (2017). Peran persepsi switching cost memoderasi customer satisfaction terhadap customer loyalty studi pelanggan PT. Bank Mandiri (Persero), Tbk. E-Jurnal Ekonomi dan Bisnis Universitas Udayana, 593-618.

Kotler, P., \& Keller. (2016). Marketing Management. England: Pearson Education Limited.

Michael. (2015). Customer Satisfaction. International Encyclopedia of the Social \& Behavioral Sciences, 2nd ed, Vol.5, pp. 6-21. 
Minh, N., \& Huu, N. (2016). The relationship between service quality, customer satisfaction, and customer loyalty (an investigation in Vietnamese retail banking sector). Journal of Competitiveness, 103-116.

Monga, A., \& John, D. (2010). What Makes Brands Elastic? The Influence of Brand Concept and Styles of Thinking on Brand Extension Evaluation. Journal of Marketing, 2-3.

Novianti, Suryoko, S., \& Nugraha, H. (2013). Pengaruh kepuasan pelanggan dan hambatan berpindah terhadap retensi pelanggan kartu prabayar Simpati di wilayah Semarang. Journal Management, 1-10.

Okazaki, S., Mueller, B., \& Diehl, S. (2013). A Multi-Country Examination of Hard-Sell and Soft-Sell Advertising : Comparing Global Consumer Positioning in Holistic- and Analytic- Thingking Cultures. Journal of Advertising Research.

Puriwat, W., \& Tripopsakul, S. (2014). The investigation of the influence of service quality toward customer engagement in service dominant industries in thailand. International Conference on Business, Management and Governance, 42-49.

Rai, A., \& Medha, S. (2013). The antecedents of customer loyalty (an empirical investigation in life insurance context. Journal of Competitiveness, 139-163.
Ramseook, S. (2010). Service quality in the public service. International Journal of marketing and marketing research, 37-41.

Risdianto, G., \& Japarianto, E. (2014). Pengaruh customer satisfaction dan switching barriers terhadap customer loyalty dengan customer trust sebagai variabel moderating pada toko buku putra togamas Surabaya. Jurnal Manajemen Pemasaran Petra, 1-10.

Riskiyati, I. (2012). Pengaruh kepuasan terhadap loyalitas dengan mediasi komitmen pada nasabah Bank BCA Ngoro Mojokerto,. Journal of Business and Banking, 241-254.

Singh, V., \& Jain, A. (2015). Consumer trust in Retail: Development of a multiple scale. Journal of Economics, Business and Management, 971-976.

So, K., King, C., Sparks, B., \& Wang, Y. (2014). The role of customer engagement in bulding consumer loyalty to tourism brands. Journal of Travel Research, 1-15.

Song, L., Swaminathan, S., \& Anderson, R. (2015). Differences in customer's online service satisfaction across cultures: the role of thinking style. Journal of Marketing Channels, 52-61.

Sugiyarmasto, \& Sudarmadi. (2012). Analisis faktor-faktor yang mempengaruhi komitmen konsumen. 1-16. 
Suparmi, \& Handhoko, K. (2018). Pengaruh kepuasan, kepercayaan dan komitmen terhadap loyalitas pelanggan pada PT. Yodya Karya (Persero) Cabang Utama Semarang. Jurnal Ilmiah UNTAG Semarang, 102-117.

Tabrani, M., Amin, M., \& Nizam, A. (2018). Trust, commitment, customer intimacy, and customer loyalty in islamic banking relationships . International Journal of Bank Marketing, 823848.

Varshney, N. (2016). Exploring service quality, switching barriers and customer loyalty: mediating role of switching barriers. Journal of Marketing and Consumer Research, 1-5.
Vivek, S., Beatty, S., \& Morgan, R. (2012). Customer engagement: exploring customer relationships beyond purchase. Journal of Marketing Theory and Practice, 127-145.

Wu, L. W. (2011). Inertia: spurious loyalty or action loyalty? Asia Pacific Management Review, 3150.

Yunus, \& Budianto. (2014). Pengaruh kualitas pelayanan dan fasilitas terhadap kepuasan pelanggan. Jurnal Ilmu dan Riset Manajemen, 1-20. 